\title{
THE IMPACT OF SMALL AND MEDIUM-SIZED FIRMS' ENTREPRENEURIAL BEHAVIOUR ON LABOUR MARKET DYNAMICS IN CENTRAL AND EASTERN EUROPE
}

\author{
NITU ANTONIE, R[enata] D[ana] \& FEDER, E[moke] - S[zidonia]
}

\begin{abstract}
The micro and macroeconomic characteristics of an economy jointly determines its competitiveness level. In order to reach an innovation-based development stage, the Central and Eastern European countries require more efficient human capital exploitation, through the active population's creative and innovative qualities exploitation, alongside with their entrepreneurial spirit. In these conditions, the paper aims to identify several cause-effect relationships between the entrepreneurial behaviour and labour market, based on the entrepreneurial process research model anchored in the Central and Eastern European countries economic development stages and competitiveness.

Keywords: entrepreneurship, entrepreneurial behaviour, entrepreneurial process, economic development stages, labour market
\end{abstract}

\section{INTRODUCTION}

Entrepreneurial behaviour is the process highlighting the ability and manifested willingness of individuals, either on their own account or in teams, inside and outside the existing organisations, to identify and create new economic opportunities (new products, new production methods, new organisational schemes and new product-market combinations), to flourish their ideas on the market by deciding on the location, form and use of resources and institutions [1], despite the perceived uncertainty and other obstacles. Entrepreneurship is the behaviour characteristic of individuals emphasized only in a certain phase of their development as active individuals within the labour market or manifested for certain type of activities [2]. Skills generating entrepreneurial spirit exist, in a greater or lesser extent, at the level of each individual and it occurs whenever incentives arise. Therefore, entrepreneurial motivations and actions are influenced both by cultural and institutional factors, by the business environment and by the macroeconomic conditions in which individuals are positioned in a given moment of time.

In Romania a positive and significant link between the basic requirements of the national framework, the conditions of the entrepreneurial framework and entrepreneurial behaviour has been ascertained. Entrepreneurial framework conditions, related to efficiency and innovation, positively influence the role of entrepreneurship and the nature of entrepreneurial activity [3]. Furthermore, entrepreneurial behaviour stimulated by the general conditions of the national and entrepreneurial framework does not generate positive effects on the labour market simultaneously, but only on medium term [4]. Starting from the prior findings and considering the objective of the New Lisbon Strategy for a more efficient capitalisation on human resources in the economies, by the means of highlighting active persons' entrepreneurial, creative and innovative features and as well the Europe 2020 Strategy aiming to ensure a high level of employment in the EU countries, consequently the main challenge is to identify factors that influence entrepreneurial behaviour and its' potential impact on the labour force market for those Central and Eastern European (CEE) countries that are included in the same economic development stage as Romania, namely Hungary, Croatia and Latvia.

The paper is organised in three parts, as follows. The next section includes the current state of art concerning the impact of the entrepreneurial framework upon entrepreneurship and the effect of the entrepreneurial behaviour on the labour market dynamics highlighted in the conceptual model of the entrepreneurial process and the derived research assumptions. The third section shows datasources and variables used for the econometric analysis and also the main findings from the statistical estimations, whereas the last section deals with conclusions and research limitations for future study.

\section{RESEARCH PROBLEM}

\subsection{Literature Review}

To assess the worldwide role of entrepreneurship on economic growth, the Global Entrepreneurship Monitor (GEM) consortium found a direct connection between the economic development stage, respectively the entrepreneurial activity level and type of a country. Due to the variety of approaches, empirical studies on the existing relationship between the emergence of new firms and job creation identified mixed results. Thus, at macroeconomic level, empirical studies emphasized contradictory and inconsistent results about the impact of new firm emergence on employment growth rate. Some studies have shown positive correlations [5], [6], others reached less clear conclusions [7], [8], [9] or even opposed results [10]. These contradictions suggest that the dynamic relationship between employment rates and firms market entry should be analysed with time-lagged effects, although most of the conducted research did not take into account delay differences or considered very short periods of time [11], [8], [12], [13], [14], [15].

At regional level, empirical studies found a positive link between the emergence of new firms and employment rate [16], [11], identifying the positive effects of a high self-employment rate on regional employment rates [12], [17]. 


\subsection{The Entrepreneurial Process Conceptual Model}

The entrepreneurial process conceptual model proposed for Romania, Croatia, Hungary and Latvia, originate in the GEM 2008 benchmark model, supplemented with several amendments [18], [19], [20], [21]. The reference model considered all the economic development stages through which a country can evaluate in time and the activity of large companies according to the general national framework conditions, respectively the entrepreneurial activity depending on the entrepreneurial framework conditions. Starting from the major stages of economic development that $\mathrm{CEE}$ countries tend to transit, like factor-, efficiency- and innovation-driven economies [22], it was deemed that only in the last two stages of development the entrepreneurial framework conditions will occur.

Keeping partially the GEM reference model design principles, the projected entrepreneurial process model for the selected CEE countries, considers a synonymy between entrepreneurship and entrepreneurial behaviour, moreover includes solely the entrepreneurial behaviour of those individuals who are starting and managing their businesses. Consequently, the model referred exclusively to Schumpeterian entrepreneurs and owner-managers of small and medium-sized businesses [1]. The first are individuals who allocate resources to start a business for exploiting opportunities from the external environment, respetively for self-employment (nascent entrepreneurs). Besides, in the same category are included entrepreneurs motivated by the necesity of self-employment, as they mainly aim to pursue opportunities, consciously or not, they may consider self-employment too. Often, after achieving the target objectives, nascent-entrepreneurs transform in owner-managers of firms, persons who starts, own and administrate new firms actively envolved on the market between 3 and 42 months, becoming established afterwards the threshold value of 3.5 years [23]. The model took into account that some of the nascent entrepreneurs leave the entrepreneurial sector because they fail to start the businesses, but actually generate effects in the economy, through the pressure they create on the existing firms.

\begin{tabular}{|c|c|c|c|c|}
\hline \multirow{2}{*}{\multicolumn{2}{|c|}{$\begin{array}{c}\begin{array}{c}\text { General conditions } \\
\text { of national } \\
\text { framework }\end{array} \\
\end{array}$}} & \multicolumn{2}{|c|}{ Entrepreneurship } & \multirow{2}{*}{$\begin{array}{l}\text { Labour } \\
\text { market } \\
\text { growth }\end{array}$} \\
\hline & & \multirow{2}{*}{$\begin{array}{c}\text { Entrepreneurial } \\
\text { attitudes and } \\
\text { perceptions }\end{array}$} & \multirow{2}{*}{$\begin{array}{c}\text { Entrepreneurial } \\
\text { activity }\end{array}$} & \\
\hline & & & & $\begin{array}{l}\text { Employment } \\
\text { rate growth }\end{array}$ \\
\hline \multicolumn{2}{|c|}{$\begin{array}{l}\text { Conditions of the } \\
\text { entrepreneurial } \\
\text { framework }\end{array}$} & & & $\begin{array}{l}\text { Newly created } \\
\text { workplaces in } \\
\text { SMEs }\end{array}$ \\
\hline $\begin{array}{l}\text { Efficiency } \\
\text { enhancers }\end{array}$ & $\begin{array}{c}\text { Innovation } \\
\text { sophistication } \\
\text { factors }\end{array}$ & & & \\
\hline
\end{tabular}

Fig. 1. The entrepreneurial process conceptual model

\subsection{Research Hypotheses}

According to the particular national contexts in Romania, Hungary, Croatia and Latvia, the justification of the applied statistical indicators is required for the correct understanding of entrepreneurship, of factors influencing the entrepreneurial behaviour and the direct impact that this behaviour may have on the labour market. In this respect, 27 pillar-indicators were engaged, grouped in: (i) indicators that define the general conditions of the national framework within a country measuring various aspects of the basic conditions necessary for the transition of a country to the next stage of economic development and competitiveness; (ii) indicators related to the conditions of the entrepreneurial framework, in order to measure various aspects of the conditions and characteristics that stimulate, sustain or hinder the entrepreneurial process; (iii) entrepreneurship indicators, which measure the dynamism of the national entrepreneurial activity by taking into account several determinants of the entrepreneurial behaviour; respectively (iv) indicators regarding the impact of entrepreneurship on the labour market dynamics, measured through the direct effects of the entrepreneurial behaviour on the newly created jobs growth rate in SMEs and the employment rate at national level (Tab. 1).

\begin{tabular}{|c|c|c|c|}
\hline Constructs & Variables & Items/ Indicators & Data source \\
\hline $\begin{array}{l}\text { General } \\
\text { conditions of } \\
\text { the national } \\
\text { framework }\end{array}$ & & \begin{tabular}{|l|} 
Institutions \\
Infrastructure \\
Macroeconomic stability \\
Health and primary \\
education \\
\end{tabular} & \multirow{3}{*}{$\begin{array}{l}\text { Global } \\
\text { Competitiveness } \\
\text { Report }\end{array}$} \\
\hline \multirow[t]{2}{*}{$\begin{array}{l}\text { Entrepreneurial } \\
\text { framework }\end{array}$} & $\begin{array}{l}\text { Efficiency } \\
\text { enhancers }\end{array}$ & \begin{tabular}{|l|} 
Higher education and \\
training \\
Goods market efficiency \\
Labour market efficiency \\
Financial market \\
sophistication \\
Technological readiness \\
Market size \\
\end{tabular} & \\
\hline & $\begin{array}{l}\text { Innovation } \\
\text { sophistication } \\
\text { factors } \\
\end{array}$ & $\begin{array}{l}\text { Business sophistication } \\
\text { Innovation }\end{array}$ & \\
\hline \multirow[b]{2}{*}{$\begin{array}{l}\text { Entrepreneur- } \\
\text { ship }\end{array}$} & \begin{tabular}{|l|} 
Entrepreneurial \\
attitudes and \\
perceptions
\end{tabular} & \begin{tabular}{|l} 
Entrepreneurial \\
intentions \\
Perceived capabilities \\
Perceived opportunities \\
Entrepreneurship as \\
desirable career choice \\
Fear of failure rate \\
Media attention for \\
entrepreneurship \\
\end{tabular} & \multirow[b]{2}{*}{$\begin{array}{l}\text { Global } \\
\text { Entrepreneurship } \\
\text { Monitor }\end{array}$} \\
\hline & \begin{tabular}{|l|} 
\\
Entrepreneurial \\
activity
\end{tabular} & \begin{tabular}{|l|} 
Nascent \\
entrepreneurship rate \\
New business ownership \\
rate \\
Early-stage \\
entrepreneurial activity \\
Established business \\
ownership rate \\
Necessity-driven/ \\
Opportunity-driven \\
entrepreneurial activity
\end{tabular} & \\
\hline $\begin{array}{l}\text { Labour market } \\
\text { growth }\end{array}$ & & $\begin{array}{l}\text { Employment rate growth } \\
\text { Newly created } \\
\text { workplaces in SMEs }\end{array}$ & $\begin{array}{l}\text { European } \\
\text { Commission, } \\
\text { International } \\
\text { Labour Org. }\end{array}$ \\
\hline
\end{tabular}

Tab. 1. Variables incorporated in the model

Depending on the economic development stage and the competitiveness of the selected CEE countries, the proposed entrepreneurial process model aims to highlight the direct cause-effect relationships, on one hand between the general conditions of the national framework, respectively of the entrepreneurial framework on entrepreneurship, on the other hand between entrepreneurship and labour market. In this respect, several hypotheses can be considered:

$\mathrm{H}_{1}$ : The general conditions of the national framework have positive impact on entrepreneurship.

$\mathrm{H}_{2}$ : The entrepreneurial framework influences positively on entrepreneurship.

$\mathrm{H}_{3}$ : The efficiency enhancing factors of the entrepreneurial framework regards positively upon entrepreneurship. 


\begin{tabular}{|c|c|c|c|c|c|c|c|c|c|c|c|c|c|}
\hline & \multicolumn{4}{|c|}{$\begin{array}{c}\text { General conditions of the } \\
\text { national framework }\end{array}$} & \multicolumn{4}{|c|}{$\begin{array}{l}\text { Conditions of the } \\
\text { entrepreneurial framework }\end{array}$} & \multicolumn{4}{|c|}{ Entrepreneurship } & \multirow{2}{*}{\begin{tabular}{|c|}
$\begin{array}{c}\text { Labour market } \\
\text { growth }\end{array}$ \\
$\mathrm{Hr}, \mathrm{Hu}, \mathrm{Lv}, \mathrm{Ro}$ \\
\end{tabular}} \\
\hline & $\mathrm{Hr}$ & $\mathrm{Hu}$ & LV & Ro & $\mathrm{Hr}$ & $\mathrm{Hu}$ & Lv & Ro & $\mathrm{Hr}$ & $\mathrm{Hu}$ & $\mathrm{Lv}$ & Ro & \\
\hline $\begin{array}{c}\text { General conditions of the } \\
\text { national framework }\end{array}$ & & & & & & & & & & \\
\hline $\begin{array}{c}\text { Conditions of the } \\
\text { entrepreneurial framework }\end{array}$ & 0.257 & 0.497 & 0.516 & -0.079 & \multicolumn{4}{|c|}{1} & & & & & \\
\hline Entrepreneurship & -0.662 & 0.049 & -0.812 & 0.749 & -0.105 & -0.380 & -0.848 & -0.195 & & 1 & & & \\
\hline Labour market growth & 0.605 & 0.089 & 0.902 & -0.831 & 0.736 & -0.397 & 0.286 & 0.272 & -0.610 & -0.398 & -0.622 & -0.534 & 1 \\
\hline
\end{tabular}

Tab. 2. Main variables correlation matrix for selected CEE countries

$\mathrm{H}_{4}$ : The innovation sophistication factors from the entrepreneurial framework acts positively on entrepreneurship. $\mathrm{H}_{5}$ : Entrepreneurship has a positive influence on the labour market growth.

$\mathrm{H}_{6}$ : Entrepreneurial perceptions and attitudes have positive outcomes regarding labour market growth.

$\mathrm{H}_{7}$ : Entrepreneurial activity has positive effects on labour market growth.

\section{SOLUTION AND EMPIRICAL RESULTS}

\subsection{Research Model Operationalisation}

The external secondary type data for the statistical analysis was collected for the 2007-2011 interval, due to the methodological changes of data inclusion and treatment from 2007 onwards regarding national competitiveness, alike the lack of entrepreneurship data before year 2007 for the selected CEE countries. Statistics regarding the general conditions of the national framework and entrepreneurial framework are sourced from the Global Competitiveness Report [19], [22], [24], [25], [26], while facts regarding the national characteristics of entrepreneurship, alike entrepreneurial perceptions, attitudes and activity, are derived from the annual national and global reports of the GEM Consortium [19], [27], [28], [29], [30]. Records about the labour market for the countries were obtained for employment rate (population over 15 year, as annual average) by querying the International Labour Organisation's LABORISTA database [20], while data for the number of new workplaces created in SMEs were obtained from the European Commission's Annual Report on European SMEs based on the annual relative difference of the number of persons employed [21].

For empirical research a simultaneous equation model was applied, based on liniar regressions between the proposed input and output variables, conducted in two steps form. In the first step, regressions were made between the general conditions of the national framework and of the entrepreneurial framework (independent variable) and entrepreneurship (dependent variable), while in the second step cause-effect relations were pursued between entrepreneurship (independent variable) and labour market (dependent variable).

\subsection{Econometrical Estimations and Main Results}

Data processing and analysis was realised by using IBM SPSS 20 software. The measuring scales are clearly defined in the World Economic Forum, GEM Consortium and International Labour Organisation's methodologies, widely accepted, assuring their internal validity and reliability.

\subsubsection{Correlations}

In conformity with the correlation matrix of the main variables (Tab. 2.), by considering their value and sign, several moderately significant patterns can be observed for the selected economies on the 2007-2011 time-lapse:

- for Croatia: the positive correlation of the general conditions of the national framework (0.605) and of the entrepreneurial framework (0.736) with labour market growth; respectively a negative association between general conditions of the national framework and entrepreneurship (-0.662), similar as entrepreneurship with labour market growth (-0.610);

- in the case of Hungary: an acceptably good link between the general conditions of the national and entrepreneurial framework (0.497), along with the conditions of the entrepreneurial framework and labour market growth (0.736);

- regarding Latvia: a single positive and remarkable relation between general conditions of the national framework and labour market growth (0.902), respectively negative significant correspondence between the basic conditions of the national framework $(-0.812)$, respectively of the entrepreneurial framework $(-0.848)$ with entrepreneurship, furthermore between entrepreneurship and labour market growth (-0.622);

- considering Romania: a positive influence between the general conditions of the national framework and entrepreneurship (0.749), while a negative one upon labour market growth $(-0.831)$, respectively a weaker correlation of the entrepreneurship with labour market growth (-0.534).

\subsubsection{Hypotheses Testing and Results}

In order to test the validity of the research hypotheses multiple linear regressions were applied tracking for each country the two-tailed significance level (p), the unstandardized value of the regression coefficient $(\beta)$, calculated value of a t test. In all the cases, a hypothesis is considered valid only if $p<0.05, \beta$ has relatively high scores and $\mathrm{t}$ exceeds the critical value of the Student repartition, in our case 2.776445 connected with the five year time-series data availability.

\begin{tabular}{|c|c|c|c|c|c|c|}
\hline $\begin{array}{l}\text { Hypo- } \\
\text { theses }\end{array}$ & $\mathbf{R}$ & $\mathbf{R}^{2}$ & $\boldsymbol{\beta}$ & $\mathbf{t}$ & $\mathbf{p}$ & Results \\
\hline $\mathrm{H}_{1}$ & 0.999 & 0.999 & 0.71768 & 112.009 & 0.00000003 & Valid \\
\hline $\mathrm{H}_{2}$ & 0.997 & 0.995 & 0.07764 & 28.727 & 0.00000087 & Valid \\
\hline $\mathrm{H}_{3}$ & 0.998 & 0.996 & 0.06502 & 32.658 & 0.0000052 & Valid \\
\hline $\mathrm{H}_{4}$ & 0.999 & 0.999 & 0.07411 & 88.340 & 0.00000009 & Valid \\
\hline $\mathrm{H}_{5}$ & 0.303 & 0.092 & 0.30206 & 0.6367 & 0.55890 & Not valid \\
\hline $\mathrm{H}_{6}$ & 0.276 & 0.076 & 0.16685 & 0.5762 & 0.59532 & Not valid \\
\hline $\mathrm{H}_{7}$ & 0.330 & 0.109 & 0.54251 & 0.7009 & 0.52197 & Not valid \\
\hline
\end{tabular}


For Croatia data analysis (Tab. 3) underlined positive significant influence for several hypotheses: $\left(\mathrm{H}_{1}\right)$ positive relationship between the general conditions of the national framework and entrepreneurship, because $\mathrm{p}<0.05 \quad(\mathrm{p}=0.00000003), \quad \beta$ has an acceptable value $(\beta=0.71768)$ and $t>2.776445(t=112.009) ;\left(\mathrm{H}_{2}\right)$ positive relationship between the entrepreneurial framework and entrepreneurship, since $\mathrm{p}<0.05(\mathrm{p}=0.00000087), \beta$ has an acceptable value $(\beta=0.07764)$ and $t>2.776445$ $(\mathrm{t}=28.727) ; \quad\left(\mathrm{H}_{3}\right)$ positive relationship between the efficiency enhancing factors of the entrepreneurial framework and entrepreneurship, in the conditions of $\mathrm{p}<0.05(\mathrm{p}=0.0000052), \beta$ has a limited value $(\beta=0.06502)$ and $\mathrm{t}>2.776445(\mathrm{t}=32.658) ;\left(\mathrm{H}_{4}\right)$ a positive relationship between innovation sophistication factors of the entrepreneurial framework and entrepreneurship, for the reason that $\mathrm{p}<0.05(\mathrm{p}=0.00000009), \beta$ has an acceptable value $(\beta=0.07411)$ and $t>2.776445(t=88.340)$. In all the above mentioned cases, a significant and highly influential $(\mathrm{R}>0.9)$ relation can be detected between the independent and dependent variables $\left(R_{1}=0.999\right.$, $\mathrm{R}_{2}=0.997, \mathrm{R}_{3}=0.998, \mathrm{R}_{4}=0.999$ ), while over the $99 \%$ of the dependent variable variation $\left(R^{2}>0.995\right)$ owes to the cumulated influence of the independent variables variation $\left(\mathrm{R}_{1}{ }^{2}=0.999, \mathrm{R}_{2}{ }^{2}=0.995, \mathrm{R}_{3}{ }^{2}=0.996, \mathrm{R}_{4}{ }^{2}=0.999\right)$.

In addition from the analysis no support was found for the further hypotheses: $\left(\mathrm{H}_{5}\right)$ negative relationship between entrepreneurship and labour market growth, because even $\beta$ has a limited value $(\beta=0.30206), p>0.05$ $(\mathrm{p}=0.55890)$ and $\mathrm{t}<2.776445(\mathrm{t}=0.6367) ;\left(\mathrm{H}_{6}\right)$ negative relationship between entrepreneurial perceptions and attitudes and labour market growth, for the reason that even $\beta$ is relatively small $(\beta=0.16685), \quad p>0.05$ $(\mathrm{p}=0.59532)$ and $\mathrm{t}<2.776445(\mathrm{t}=0.5762) ;\left(\mathrm{H}_{7}\right)$ negative relationship between entrepreneurial activity and labour market growth, as $\beta$ is quite low $(\beta=0.54251), p>0.05$ $(\mathrm{p}=0.52197)$ and $\mathrm{t}<2.776445(\mathrm{t}=0.7009)$. In the cases of mentioned hypotheses, a limited $(\mathrm{R}>0.25)$ association can be noticed between the independent and dependent variables $\left(\mathrm{R}_{5}=0.303, \mathrm{R}_{6}=0.276, \mathrm{R}_{7}=0.330\right)$, while less than $8 \%$ of the dependent variable variation $\left(R^{2}>0.076\right)$ owes to the cumulated influence of the independent variables $\left(\mathrm{R}_{5}^{2}=0.092, \mathrm{R}_{6}{ }^{2}=0.076, \mathrm{R}_{7}{ }^{2}=0.109\right)$.

\begin{tabular}{|c|c|c|c|c|c|c|}
\hline $\begin{array}{c}\text { Hypo- } \\
\text { theses }\end{array}$ & $\mathbf{R}$ & $\mathbf{R}^{2}$ & $\boldsymbol{\beta}$ & $\mathbf{t}$ & $\mathbf{p}$ & Results \\
\hline $\mathrm{H}_{1}$ & 0,999 & 0,998 & 0,92623 & 61,8530 & 0,0000004 & Valid \\
\hline $\mathrm{H}_{2}$ & 0,999 & 0,998 & 0,05034 & 46,376 & 0,0000012 & Valid \\
\hline $\mathrm{H}_{3}$ & 0,999 & 0,998 & 0,04928 & 48,44932 & 0,000011 & Valid \\
\hline $\mathrm{H}_{4}$ & 0,998 & 0,996 & 0,05639 & 32,80962 & 0,000051 & Valid \\
\hline $\mathrm{H}_{5}$ & 0,149 & 0,022 & 0,59908 & 0,302071 & 0,77765 & Not valid \\
\hline $\mathrm{H}_{6}$ & 0,128 & 0,016 & 0,34348 & 0,25822 & 0,80897 & Not valid \\
\hline $\mathrm{H}_{7}$ & 0,164 & 0,027 & 0,96833 & 0,33367 & 0,75538 & Not valid \\
\hline
\end{tabular}

$\mathrm{R}$ - multiple $\mathrm{R} ; \mathrm{R}^{2}-\mathrm{R}$ square; $\mathrm{p}$ - significance level, $\beta$ unstandardized regression coefficient, $\mathrm{t}$ - calculated value for Student test

Tab. 4. Results of research hypotheses tested for Hungary

For Hungary, data analysis (Tab. 4) emphasized positive significant influence for several hypotheses: $\left(\mathrm{H}_{1}\right)$ positive relationship exists between the general conditions of the national framework and entrepreneurship, because $\mathrm{p}<0.05(\mathrm{p}=0.0000004), \beta$ has a high value $(\beta=0.92623)$, and $t>2.776445(t=61.8530)$; $\left(\mathrm{H}_{2}\right)$ positive relationship between the entrepreneurial framework and entrepreneurship, since $\mathrm{p}<0.05$ $(\mathrm{p}=0.0000012), \beta$ has an acceptable value $(\beta=0.05034)$ and $\mathrm{t}>2.776445(\mathrm{t}=46.376) ;\left(\mathrm{H}_{3}\right)$ positive relationship between the efficiency enhancing factors of the entrepreneurial framework and entrepreneurship, in the conditions of $\mathrm{p}<0.05(\mathrm{p}=0.000011), \beta$ has an acceptable value $(\beta=0.04928)$ and $\mathrm{t}>2.776445(\mathrm{t}=48.44932) ;\left(\mathrm{H}_{4}\right)$ positive relationship between the innovation sophistication factors of the entrepreneurial framework and entrepreneurship, for the reason that $p<0.05$ $(p=0.000051), \beta$ has an acceptable value $(\beta=0.05639)$ and $t>2.776445(t=32.80962)$. In all the mentioned cases, $a$ significant and highly influential $(\mathrm{R}>0.99)$ relation can be detected between the independent and dependent variables $\left(R_{1}=0.999, R_{2}=0.999, R_{3}=0.999, R_{4}=0.998\right)$, while over the $99 \%$ of the dependent variable variation $\left(\mathrm{R}^{2}>0.996\right)$ owes to the cumulated influence of the independent variables variation $\left(\mathrm{R}_{1}{ }^{2}=0.998, \mathrm{R}_{2}{ }^{2}=0.998\right.$, $\left.\mathrm{R}_{3}{ }^{2}=0.998, \mathrm{R}_{4}^{2}=0.996\right)$.

In addition from the analysis no support was found for the further hypotheses: $\left(\mathrm{H}_{5}\right)$ negative relationship between entrepreneurship and labour market growth, because even $\beta$ has a fairly low value $(\beta=0.59908)$, $\mathrm{p}>0.05(\mathrm{p}=0.77765)$ and $\mathrm{t}<2.776445(\mathrm{t}=0.302071) ;\left(\mathrm{H}_{6}\right)$ negative relationship between the entrepreneurial perceptions and attitudes (independent variable) and labour market growth (dependent variable), for the reason that even $\beta$ is relatively small $(\beta=0.34348)$, $\mathrm{p}>0.05(\mathrm{p}=0.80897)$ and $\mathrm{t}<2.776445(\mathrm{t}=0.25822) ;\left(\mathrm{H}_{7}\right)$ negative relationship between entrepreneurial activity (independent variable) and labour market growth (dependent variable), as is quite low $(\beta=0.96833)$, but $\mathrm{p}>0.05(\mathrm{p}=0.75538)$ and $\mathrm{t}<2.776445(\mathrm{t}=0.33367)$. In the cases of $\left(\mathrm{H}_{5}\right)-\left(\mathrm{H}_{7}\right)$ hypotheses, less than acceptable $(\mathrm{R}<0.25)$ association can be noticed between the independent and dependent variables $\left(\mathrm{R}_{5}=0.149\right.$, $\left.\mathrm{R}_{6}=0.128, \mathrm{R}_{7}=0.164\right)$, less than $2 \%$ of the dependent variable variation $\left(\mathrm{R}^{2}>0.016\right)$ owes to the cumulated influence of the independent variables $\left(\mathrm{R}_{5}{ }^{2}=0.022\right.$, $\mathrm{R}_{6}^{2}=0.016, \mathrm{R}_{7}^{2}=0.027$ ).

\begin{tabular}{|c|c|c|c|c|c|c|}
\hline $\begin{array}{c}\text { Hypo- } \\
\text { theses }\end{array}$ & $\mathbf{R}$ & $\mathbf{R}^{\mathbf{2}}$ & $\boldsymbol{\beta}$ & $\mathbf{t}$ & $\mathbf{p}$ & Results \\
\hline $\mathrm{H}_{1}$ & 0,999 & 0,999 & 0,88930 & 104,41052 & 0,00000007 & Valid \\
\hline $\mathrm{H}_{2}$ & 0,993 & 0,987 & 0,06048 & 17,72154 & 0,0000596 & Valid \\
\hline $\mathrm{H}_{3}$ & 0,993 & 0,987 & 0,05861 & 17,78242 & 0,0000588 & Valid \\
\hline $\mathrm{H}_{4}$ & 0,993 & 0,986 & 0,07192 & 17,03899 & 0,0000696 & Valid \\
\hline $\mathrm{H}_{5}$ & 0,280 & 0,078 & $-3,80061$ & $-0,58383$ & 0,590675 & Not valid \\
\hline $\mathrm{H}_{6}$ & 0,223 & 0,049 & $-1,95173$ & $-0,4584$ & 0,670466 & Not valid \\
\hline $\mathrm{H}_{7}$ & 0,333 & 0,111 & $-6,91571$ & $-0,70809$ & 0,517969 & Not valid \\
\hline
\end{tabular}

$\mathrm{R}$ - multiple $\mathrm{R} ; \mathrm{R}^{2}-\mathrm{R}$ square; $\mathrm{p}$ - significance level, $\beta$ unstandardized regression coefficient, $\mathrm{t}$ - calculated value for Student test

Tab. 5. Results of research hypotheses tested for Latvia

For Latvia, data analysis (Tab. 5) highlighted positive significant influences for several hypotheses: $\left(\mathrm{H}_{1}\right)$ positive relationship exists between the general conditions of the national framework and entrepreneurship, because $p<0.05(p=0.00000007), \beta$ has a high value $(\beta=0.88930)$, and $t>2.776445$ $(\mathrm{t}=104.41052) ;\left(\mathrm{H}_{2}\right)$ positive relationship between the entrepreneurial framework and entrepreneurship, since $\mathrm{p}<0.05 \quad(\mathrm{p}=0.0000596), \quad \beta$ has an acceptable value $(\beta=0.06048)$ and $t>2.776445(t=17.72154) ;\left(H_{3}\right)$ positive 
relationship between the efficiency enhancing factors of the entrepreneurial framework and entrepreneurship, in the conditions of $\mathrm{p}<0.05 \quad(\mathrm{p}=0.0000588), \quad \beta$ has an acceptable value $(\beta=0.05861)$ and $\mathrm{t}>2.776445$ $(\mathrm{t}=17.78242) ;\left(\mathrm{H}_{4}\right)$ positive relationship between the innovation sophistication factors of the entrepreneurial framework and entrepreneurship, for the reason that $\mathrm{p}<0.05 \quad(\mathrm{p}=0.0000696), \quad \beta$ has an acceptable value $(\beta=0.07192)$ and $t>2.776445 \quad(t=17.03899)$. In all the mentioned cases, a significant and influential $(\mathrm{R}>0.9)$ relation can be detected between the independent and dependent variables $\left(\mathrm{R}_{1}=0.999, \mathrm{R}_{2}=0.993, \mathrm{R}_{3}=0.993\right.$, $\mathrm{R}_{4}=0.993$ ), while over the $98 \%$ of the dependent variable variation $\left(R^{2}>0.974\right)$ owes to the cumulated influence of the independent variables variation $\left(\mathrm{R}_{1}{ }^{2}=0.999\right.$ $\mathrm{R}_{2}{ }^{2}=0.987, \mathrm{R}_{3}{ }^{2}=0.987, \mathrm{R}_{4}{ }^{2}=0.986$ ).

In addition from the analysis no support was found for the further hypotheses: $\left(\mathrm{H}_{5}\right)$ negative relationship between entrepreneurship and labour market growth, because even $\beta$ has a fairly low value $(\beta=-3.800609)$, $\mathrm{p}>0.05(\mathrm{p}=0.590675)$ and $\mathrm{t}<2.776445(\mathrm{t}=-0.58383) ;\left(\mathrm{H}_{6}\right)$ negative relationship between the entrepreneurial perceptions and attitudes and labour market growth, for the reason that even $\beta$ is relatively small $(\beta=-1.95173)$, $\mathrm{p}>0.05(\mathrm{p}=0.670466)$ and $\mathrm{t}<2.776445(\mathrm{t}=-0.4584) ;\left(\mathrm{H}_{7}\right)$ negative relationship between entrepreneurial activity and labour market growth, as is quite low $(\beta=-6.91571)$, but $\mathrm{p}>0.05(\mathrm{p}=0.517969)$ and $\mathrm{t}<2.776445(\mathrm{t}=-0.70809)$. In the cases of $\left(\mathrm{H}_{5}\right)-\left(\mathrm{H}_{7}\right)$ hypotheses, a moderately good or acceptable $(\mathrm{R}>0.2)$ association can be noticed between the independent and dependent variables $\left(\mathrm{R}_{5}=0.280\right.$, $\mathrm{R}_{6}=0.223, \mathrm{R}_{7}=0.333$ ), less than $5 \%$ of the dependent variable variation $\left(R^{2}>0.049\right)$ owes to the cumulated influence of the independent variables $\left(\mathrm{R}_{5}{ }^{2}=0.078\right.$, $\mathrm{R}_{6}^{2}=0.049, \mathrm{R}_{7}^{2}=0.111$ ).

\begin{tabular}{|c|c|c|c|c|c|c|}
\hline $\begin{array}{c}\text { Hypo- } \\
\text { theses }\end{array}$ & $\mathbf{R}$ & $\mathbf{R}^{\mathbf{2}}$ & $\boldsymbol{\beta}$ & $\mathbf{t}$ & $\mathbf{p}$ & Results \\
\hline $\mathrm{H}_{1}$ & 0,999 & 0,998 & 0,95627 & 58,87912 & 0,0000004 & Valid \\
\hline $\mathrm{H}_{2}$ & 0,991 & 0,995 & 0,05539 & 15,6538 & 0,0000973 & Valid \\
\hline $\mathrm{H}_{3}$ & 0,992 & 0,985 & 0,05376 & 16,31746 & 0,0000826 & Valid \\
\hline $\mathrm{H}_{4}$ & 0,986 & 0,974 & 0,06517 & 12,26731 & 0,000253 & Valid \\
\hline $\mathrm{H}_{5}$ & 0,611 & 0,374 & $-3,95268$ & $-1,546513$ & 0,1968828 & Not valid \\
\hline $\mathrm{H}_{6}$ & 0,601 & 0,362 & $-2,37456$ & $-1,50776$ & 0,206100 & Not valid \\
\hline $\mathrm{H}_{7}$ & 0,613 & 0,383 & $-6,52577$ & $-1,57903$ & 0,189474 & Not valid \\
\hline
\end{tabular}

$\mathrm{R}$ - multiple R; $\mathrm{R}^{2}-\mathrm{R}$ square; $\mathrm{p}$ - significance level, $\beta$ unstandardized regression coefficient, $\mathrm{t}$ - calculated value for Student test

Tab. 6. Results of research hypotheses tested for Romania

For Romania, data analysis (Tab. 6) revealed significant influence for several hypotheses: $\left(\mathrm{H}_{1}\right)$ positive relationship exists between the general conditions of the national framework and entrepreneurship, because $\mathrm{p}<0.05(\mathrm{p}=0.0000004), \beta$ has a relatively high value $(\beta=0.95627)$, and $\mathrm{t}>2.776445$ $(\mathrm{t}=58.87912) ;\left(\mathrm{H}_{2}\right)$ positive relationship between the entrepreneurial framework and entrepreneurship, since $\mathrm{p}<0.05(\mathrm{p}=0.0000973), \quad \beta$ has an acceptable value $(\beta=0.05539)$ and $\mathrm{t}>2.776445(\mathrm{t}=15.6538) ;\left(\mathrm{H}_{3}\right)$ positive relationship between the efficiency enhancing factors of the entrepreneurial framework and entrepreneurship, in the conditions of $p<0.05 \quad(p=0.0000826), \beta$ has an acceptable value $(\beta=0.05376)$ and $\mathrm{t}>2.776445$ $(\mathrm{t}=16.31746) ;\left(\mathrm{H}_{4}\right)$ positive relationship between the innovation sophistication factors of the entrepreneurial framework and entrepreneurship, for the reason that $\mathrm{p}<0.05(\mathrm{p}=0.000253), \quad \beta$ has an acceptable value $(\beta=0,06517)$ and $t>2.776445 \quad(t=12,26731)$. In all the mentioned cases, a significant and influential $(\mathrm{R}>0.9)$ relation can be detected between the independent and dependent variables $\left(\mathrm{R}_{1}=0.999, \mathrm{R}_{2}=0.991, \mathrm{R}_{3}=0.992\right.$, $\mathrm{R}_{4}=0.986$ ), while over the $97 \%$ of the dependent variable variation $\left(R^{2}>0.974\right)$ owes to the cumulated influence of the independent variables variation $\left(\mathrm{R}_{1}{ }^{2}=0.998\right.$, $\mathrm{R}_{2}{ }^{2}=0.995, \mathrm{R}_{3}{ }^{2}=0.985, \mathrm{R}_{4}{ }^{2}=0.974$ ).

In addition from the analysis no support was found for the further hypotheses: $\left(\mathrm{H}_{5}\right)$ negative relationship between entrepreneurship (independent variable) and labour market growth (dependent variable), because even $\beta$ has a fairly low value $(\beta=-3.95268), \quad \mathrm{p}>0.05$ $(\mathrm{p}=0.1968828)$ and $\mathrm{t}<2.776445 \quad(\mathrm{t}=-1.546513) ; \quad\left(\mathrm{H}_{6}\right)$ negative relationship between the entrepreneurial perceptions and attitudes and labour market growth, for the reason that even $\beta$ is relatively small $(\beta=-2.37456)$, $\mathrm{p}>0.05(\mathrm{p}=0.206100)$ and $\mathrm{t}<2.776445(\mathrm{t}=-1.50776) ;\left(\mathrm{H}_{7}\right)$ negative relationship between entrepreneurial activity and labour market growth, as is quite low $(\beta=-6.52577)$, but $\mathrm{p}>0.05(\mathrm{p}=0.189474)$ and $\mathrm{t}<2.776445(\mathrm{t}=-1.57903)$. In the cases of $\left(\mathrm{H}_{5}\right)-\left(\mathrm{H}_{7}\right)$ hypotheses, a moderately good $(\mathrm{R}>0.5)$ association can be noticed between the independent and dependent variables $\left(\mathrm{R}_{5}=0.611\right.$, $\mathrm{R}_{6}=0.601, \mathrm{R}_{7}=0.613$ ), but even as, less than $37 \%$ of the variation of the dependent variable $\left(\mathrm{R}^{2}>0.362\right)$ owes to the cumulated influence of the independent variables $\left(\mathrm{R}_{5}{ }^{2}=0.374, \mathrm{R}_{6}{ }^{2}=0.362, \mathrm{R}_{7}{ }^{2}=0.383\right)$.

The overall conclusion demonstrated a general positive pattern for hypotheses regarding the basic national requirements, entrepreneurial conditions and entrepreneurship, while their current direct impact on the labour market is lacking. Consequently, hypotheses $\left(\mathrm{H}_{1}\right)$ $\left(\mathrm{H}_{4}\right)$ have been validated, whereas hypotheses $\left(\mathrm{H}_{5}\right)-\left(\mathrm{H}_{7}\right)$ were not supported, for the second category of hypotheses there are an important number of other factors with direct effect acting upon the labour market. The conclusion is individually proper in each of the examined CEE country.

\section{CONCLUSIONS, LIMITATIONS AND FUTURE RESEARCH DIRECTIONS}

The performed analysis revealed a positive and significant link between the general conditions of the national framework, respectively of the entrepreneurial framework (also for its components: efficiency enhancers and innovation sophistication factors) and entrepreneurial behaviour. Consequently, within the countries subject of the analysis, the presence of an adequate infrastructure, a satisfactory level of primary education and good health, constitute the starting point to ensure the indispensable conditions of the entrepreneurial framework, as efficiency and innovation. These competitiveness factors influence in a positive sense the role entrepreneurial activity and the nature of entrepreneurship. In addition, from the accomplished research resulted that, entrepreneurial behaviour stimulated by the general conditions of the national and entrepreneurial framework does not generate, always simultaneously, positive effects on the labour market, in the form of increasing the employment rate and the number of newly created jobs. Entrepreneurial behaviour can be perceived as a factor of 
labour force employment, but not necessarily at the same time, since the emergence of new firms, due to encouraged opportunity- and necessity-driven entrepreneurship, are concurrently creating and destroying jobs, because they encourage competition resulting in the exit of less efficient firms from the market. In these conditions, the effects on the labour market are given by the interaction results between the consequence of firms' entry and exit from the market [9]. Rooted in the goals of the Europe 2020 Strategy and the objective to obtain high level workforce employment within each analysed CEE country, results lead to the conclusion that public authorities should stimulate entrepreneurial behaviour by improving the institutional framework in which it occurs, by reducing taxation and reviewing national regulations and codes regarding the employed workforce, with the purpose to ensure positive effects on the labour market, at least on medium- and long term.

Research limitations are generated by the lack of relevant statistical data for CEE countries, which imposed restrictions in the scope of analysis unit, to the level of a few countries and the impossiblity to include the entrepreneurial behaviour of large established firms (intrapreneurship) manifested domestically and internationally. Future research directions intend to consider, on one hand, the transformation of the proposed model in a time-lagged one by using longer time series or variables delayed in time, which could permit the validation of all research hypotheses, and on the other hand, the description of the labour market by using multiple growth indicators, for richer informational content.

\section{ACKNOWLEDGEMENTS}

The paper received financial support through "Postdoctoral Studies in Economics: Training program for leading researchers - SPODE", co-financed by the European Social Funds, Human Resources Development Operational Programme 2007-2013, contract no. POSDRU/89/1.5/S/61755.

\section{REFERENCES}

[1] Wennekers, S. \& Thurik, R. (1999). Linking Entrepreneurship and Economic Growth, Small Business Economics, Vol. 13, No. 1, pp. 27-55

[2] Carree, M. \& Thurik, R. (2005). The Impact of Entrepreneurship on Economic Growth, Handbook of Entrepreneurship Research, International Handbook Series on Entrepreneurship, Vol. 1, Part 7, pp. 437-471

[3] Nițu-Antonie, R.; Feder E-Sz., Sîrghi, N. \& Hațegan, C. (2010a) Entrepreneurship and Its Effects on the Romanian Labour Market, International Journal of Communications, Nr. 3, Vol. 4, NAUN Press, ISSN: 1998-4480, pp. 84-93

[4] Niţu-Antonie, R.; Feder E-Sz., Sîrghi, N. \& Hațegan, C. (2010b) Study Regarding the Role of Entrepreneurship in Romania within the Labour Market Dynamics, Proceedings of the $5^{\text {th }}$ WSEAS International Conference on Economy and Management Transformation, (Vol. II), ISBN: 978-960-474-241-7, WSEAS Press, pp. 585 - 590

[5] Ashcroft, B.; Love, J. H. \& Malloy, E. (1996). New Firm Formation in the British Counties with Special Reference to Scotland, Regional Studies, Vol. 25, No. 5, 1996, pp. 395-409

[6] Baptista, R.; Escaria, V. \& Madruga, P. (2005). Entrepreneurship, Regional Development and Job Creation: the Case of Portugal, Max Planck Institute for Research into Economic Systems, pp. 145
[7] Fritsch, M. (1996). Turbulence and growth in West-Germany: A comparison of evidence by regions and industries, Review of Industrial Organization, Vol. 11, pp. 231-251

[8] Audretsch, D. \& Fritsch, M. (2002). Growth Regimes over Time and Space, Regional Studies, Vol. 36, No. 2, pp. 113-124

[9] Carod Arauzo, J.M.; Solis, D. L. \& Bofarull, M., (2008). New Business Formation and Employment Growth: some Evidence for the Spanish Manufacturing Industry, Small Business Economics, Vol. 30, No. 1, pp. 73-84

[10] Baptista, R. \& Thurik, A.R. (2007). Relationship between Entrepreneurship and Employment: is Portugal an Outlier?, Technological and Social Change, Vol. 75, pp. 75-89

[11] Ács, Z. J. \& Armington, C. (2004). Employment Growth and Entrepreneurial Activity in Cities, Regional Studies, Vol. 38, No. 8, pp. 911-927

[12] Folster, S. (2000). Do Entrepreneurs Create Jobs?, Small Business Economics, Vol. 14, No. 2, pp. 137-148

[13] Fritsch, M. \& Mueller, P. (2004). Effects of New Business Formation on Regional Development over Time, Regional Studies, Vol. 38, No. 8, pp. 961-975

[14] Fritsch, M.; Mueller, P. \& Weyh, A. (2005). Direct and Indirect Effects of New Business Formation on Regional Employment, Applied Economics Letters, Vol. 12, No. 9, pp. 545-548

[15] Van Stel, A. \& Storey, D. (2004). Link Between Firm Births and Job Creation: Is there a Upas Tree Effect?, Regional Studies, Vol. 38, No. 8, pp. 893-909

[16] Reynolds, P. D. (1999). Creative destruction: Source or symptom of economic growth? in Entrepreneurship, small and mediumsized enterprises and the macroeconomy, Ács, Z.J., Carlsson, B., Karlsson, C., (eds.), Cambridge University Press, pp. 97-136

[17] Brixy, U. \& Grotz, R. (2004). Entry-Rates, the Share of Surviving Business and Employment Growth: Differences between Western an Eastern Germany since Reunification, in Advances in Interdisciplinary European Entrepreneurship Research, Dowling, M., Schmude, J., Knyphausen-Aufsess D. (eds)., Münster Lit, pp.143 - 152

[18] Sala-I Martin, X.; Blanke, J., Drzeniek Hanouz, M., Geiger, T. \& Mia, I. (2009). Global Competitiveness Report 2009-2010, World Economic Forum

[19] Bosma, N.; Ács, Z. J., Autio, E., Coduras, A. \& Levie, J., (2009). Global Entrepreneurship Monitor 2008-Executive Report, Global Entrepreneurship Research Association

[20] International Labour Organisation, Economically Active Population Estimates and Projections 1990-2020, LABORISTA Database, update of October 2011, Available from: http://laborsta.ilo.org/applv8/data/EAPEP/eapep_E.html, Accessed on: 2012-05-22

[21] European Commission, Database for the Annual Report on European SMEs, Available from: http://ec.europa.eu/enterprise/policies/smelfacts-figuresanalysis/performance-review/index_en.htm\#h2-3, Accessed on: 2012-05-22

[22] Porter, M. \& Schwab, K. (2008). The Global Competitiveness Report 2008-2009, Word Economic Forum

[23] Reynolds, P.; Bosma, N., Autio, E., Hunt, S., De Bono, N., Servais, I., Lopez-Garcia, P. \& Chin, N. (2005). Entrepreneurship Monitor: Data Collection Design and Implementation 1998-2003, Small Business Economics, Vol. 24, No. 5, 2005, pp. 205-231

[24] Porter, M.; Sala-I Martin, X., Blanke, Mia, I. \& Geiger, T. (2007). The Global Competitiveness Report 2007-2008, World Economic Forum

[25] Schwab, K.; Sala-I Martin, X. \& Greenhill, R. (2010). The Global Competitiveness Report 2010-2011, World Economic Forum

[26] Schwab, K.; Sala-I Martin, X. \& Greenhill, R. (2011). The Global Competitiveness Report 2011-2012, World Economic Forum

[27] Bosma, N.; Jones, K., Autio, E. \& Levie, J. (2008). Global Entrepreneurship Monitor 2007 - Executive Report, Global Entrepreneurship Research Association

[28] Bosma, N.; Levie, J., Bygrave, D., Justo, R., Lepoutre, J. \& Terjesen, S. (2010). Global Entrepreneurship Monitor 2009 Executive Report, Global Entrepreneurship Research Association

[29] Kelley, D. J.; Bosma, N. \& Amorós J.E. (2011). 2010 Global Report, Global Entrepreneurship Research Association

[30] Bosma, N.; Wennekers, S. \& Amorós J.E. (2012). 2011 Extended Report: Entrepreneurs and Entrepreneurial Employees Across the Globe, Global Entrepreneurship Research Association 